\title{
Accounting
}

\section{Customer value is reviewed in terms of customer relationship learning and customer engagement: Evidence from banking industry}

\author{
Feliks Anggia B.K. Panjaitan ${ }^{a^{*}}$ and Hotman Panjaitan ${ }^{a}$
}

\section{H R O N I C L E} \\ Article history: \\ Received: July 2, 2020 \\ Received in revised format: \\ September 302020 \\ Accepted: October 8, 2020 \\ Available online: \\ October 12,2020 \\ Keywords: \\ Service quality \\ Customer relationship learning \\ Product quality \\ Customer engagement \\ Customer value
}

${ }^{a}$ Universitas 17 Agustus 1945 Surabaya, Indonesia

\section{A B S T R A C T}

This study is to examine the effects of service quality, customer relationship learning, product quality, and customer engagement on increasing customer value. The researchers propose a model, and plan to show the concept of customer engagement variables as intervening variables. The study population includes the customers of Bank Jatim and uses the SEM analysis and the purposive sampling method for 384 respondents. The proposed model shows customer engagement acts as a good intervening variable. Customer value increases, as customer engagement increases. Finally, customer relationship learning determines the value of the existence of customer engagement in bank service customers.

\section{Introduction}

Competition is very important for the success of the company. The competitive strategy aims to foster a profitable and strong position in the company. The application of customer relationship learning (CRL) as an effort aims to educate consumers so they realize the importance of company services in supporting the smooth running of their daily activities. The learning and absorption capacity influence the company's innovation performance, which in turn has a positive effect on firm excellence (Chen et al., 2009). Eng (2005) states that a company's ability to learn from its network of business relationships is an important source and can be processed into value for CRL as long as the company provides good quality services (Heri, 2017). In addition to service and product quality, consumer involvement also plays an important role for the success of the firms. Ghofur (2017) found that customer value has no effect on customer engagement (CE). This study connects CRL to customer value through CE, where this relationship is an important observation of this paper.

\section{Literature review and hypotheses}

Excellent service is caring for customers by providing the best service to facilitate the ease of meeting needs, and to realize satisfaction so that they are loyal to the company (Johnston, 2017). For companies engaged in the service sector, providing quality services to customers is an absolute thing when the company attemps to achieve success. Darwin et al. (2017); Nammir et al. (2012); Hapsari (2015), emphasize the importance of customer involvement in the service industry sector and its contribution on the quality of service. Customer involvement has an important role in developing loyalty (Manggarani, 2018).

* Corresponding author.

E-mail address: felikscp23@gmail.com (F. A. B.K. Panjaitan) 
Chang et al. (2019); VO et al. (2019) emphasize that relational bonds influence the level of customer involvement, which in turn influences service quality, increases satisfaction and consumer engagement behavior. So the hypothesis:

\section{$\mathrm{H}_{1}$ : Service quality contributes to increasing customer engagement.}

Learning as a change in behavior is relatively fixed, which occurs as a result of experience (Cialdini, 2010). While reflex is an accidental behavior that occurs in response to a stimulus. From a marketing perspective, customer relationship learning is a process in which a person acquires knowledge that will be applied to related behaviors in the future. Consumer learning is a process, which is constantly evolving and changing, because of the newly acquired knowledge that may be obtained from reading, from discussion, observation, and from the thought process or from observation itself. Chen et al. (2009), showed a positive relationship between learning and absorption capacity on the performance of corporate innovation. Selnes and Sallis (2009), state that organizations can strengthen their learning abilities with targeted customers. Šonková, and Grabowska (2015), state that the process of applying the right relationship marketing strategy, will result in successful relationship marketing. Thus, we propose the following hypothesis:

\section{$\mathrm{H}_{2}$ : Customer relationship learning contributes to increasing customer engagement.}

Itani et al. (2019) states that the perception and quality of the relationship has an impact on CE. Harryan (2017) states that a good customer relationship management (CRM) will increase customer value (CV), product quality and service quality. While Hollebeek (2012) states CE positively contributes to CV, while Rivai, and Wahyudi (2016), find the opposite. So the hypothesis:

\section{$\mathrm{H}_{3}$ : Product quality contributes to increase customer engagement.}

So et al. (2014), state that CE can be used as a measurement tool for how strong a customer relationship a company has based on the emotional and rational attachment of customers to the brand (Bowden, 2009). Brodie et al. (2011), state that the process of CE starts from a customer's need for information about a product / service / company that requires an interactive and a sense of belonging relationship. Ateke and Iruka (2015), stated that CE management is a viable strategy to drive marketing performance. According to Oswald et al. (2004), customer involvement can provide ongoing customer feedback and enable a more objective assessment of quality, and can increase customer satisfaction. Leong et al. (2017), states that consumer involvement and consumer interest can affect consumer loyalty. Hapsari et al. (2017); Banytea, and Dovaliene, (2014), stated that customer involvement can create value. Thus, we propose the following hypothesis:

\section{$\mathrm{H}_{4}$ : Customer involvement contributes to increasing customer value.}

\section{Research Methodes}

This research was a causal research. The study population included all Indonesian East Java bank customers. The analysis technique uses SEM analysis with the help of Amos software. Estimates were performed using Generalized Least Square Estimation (GLS), and the number of samples studied was 384 respondents, obtained from the formula Lemeshow et al. (1997), with a 5\% sampling error. While the sampling method uses purposive sampling.

\subsection{Instrumen dan indikator variabel}

The study uses a questionnaire with a 5 level Likert scale. The service quality variable uses 6 indicators adopted from Hawkins et al. (2013), namely: ability, appearance, attention, accuracy, friendliness, and comfort. Customer relationship learning uses 3 indicators adopted from Solomon (2013), namely: repetition, stimulus generalization, stimulus discrimination. Product quality uses 4 indicators adopted from Ishaq et al. (2014), namely: performance, features, reliability, and conformance. Customer engagement has 3 indicators adopted from Naomi (2015), namely: cognitive attachments, attitudinal attachments, and behavioral attachments. Customer value has 4 indicators adjusted from Panjaitan, and Komari (2018), namely: emotional value, social value, quality / performance value, and price / value of money.

\section{Results and Discussion}

\subsection{Descriptive data analysis}

Descriptive data analysis of 384 respondents showed that: according to male dominant gender was $69.8 \%$, while women were $30.2 \%$. In terms of age, $26.5 \%$ of the respondents aged 17-30 years while most of them aged 31-40 years (39.9\%). The educational level of the majority of respondents was a bachelor $(56.5 \%)$, while the rest had a high school education by $33.0 \%$ and postgraduate of $10.4 \%$. The length of time respondents becomes customers is in the range of $1-2$ years, $11.5 \%, 3-5$ years, $36.2 \%$, and more than 5 years as much as $52.3 \%$. 


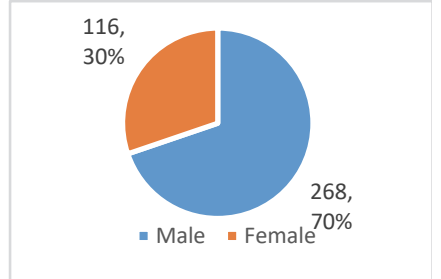

Gender

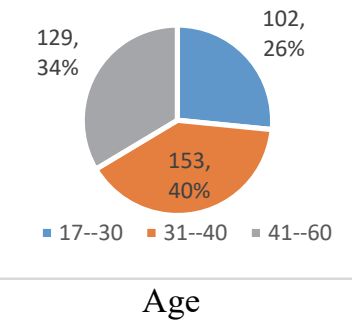

Age

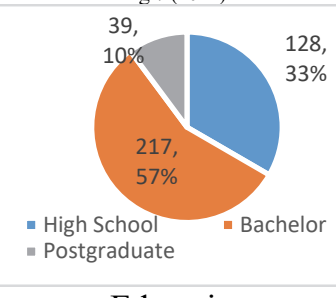

Education

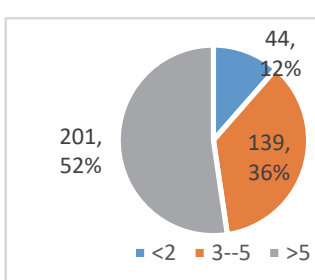

Long term customer (Year)

\subsection{Instrument Validity and Reliability Test}

From the results of the Pearson product moment correlation analysis (Table 1), it is known that all the question items in the questionnaire have a significant correlation at an error rate of $5 \%$, so it can be said that all question items are valid (Hair et al., 2016).

\section{Table 1}

The validity and reliability test

\begin{tabular}{|c|c|c|c|}
\hline Research variables & Indicator & Question Number & Pearson correlation \\
\hline \multirow[t]{6}{*}{ Service quality } & Sqa1 & $1-2$ & $0.789 * *$ \\
\hline & $\mathrm{Sqa} 2$ & $3-4$ & $0.797 * *$ \\
\hline & Sqa3 & $5-6$ & $0.801 * *$ \\
\hline & Sqa4 & $7-8$ & $0.767 * *$ \\
\hline & Sqa5 & $9-10$ & $0.801 * *$ \\
\hline & Sqa6 & $11-12$ & $0.728 * *$ \\
\hline \multirow[t]{3}{*}{ Customer relationship learning } & Crl1 & $13-14$ & $0.708 * *$ \\
\hline & $\mathrm{Crl} 2$ & $15-16$ & $0.811 * *$ \\
\hline & $\mathrm{Cr} 13$ & $17-18$ & $0.752 * *$ \\
\hline \multirow{4}{*}{ Product quality } & Prq1 & $19-20$ & $0.724 * *$ \\
\hline & Prq2 & $21-22$ & $0.676^{* *}$ \\
\hline & Prq3 & $23-24$ & $0.716^{* *}$ \\
\hline & Prq4 & $25-26$ & $0.774 * *$ \\
\hline \multirow{3}{*}{ Customer engagement } & Eng1 & $27-28$ & $0.770 * *$ \\
\hline & Eng2 & $29-30$ & $0.832 * *$ \\
\hline & Eng3 & $31-32$ & $0.818 * *$ \\
\hline \multirow{4}{*}{ Customer value } & Vall & $33-34$ & $0.678 * *$ \\
\hline & Val2 & $35-36$ & $0.782 * *$ \\
\hline & Val3 & $37-38$ & $0.751 * *$ \\
\hline & Val4 & $39-40$ & $0.734 * *$ \\
\hline
\end{tabular}

**. Correlation is significant at the 0.01 level (2-tailed).

\subsection{Confirmatory factor analysis.}

Table 2, informs that all manifests are significant in shaping latent variables, and have a construct critical ratio of more than 0.2, which means they are from one dimension (unidimensional).

\section{Table 2}

Confirmatory Factor Analysis

\begin{tabular}{|c|c|c|c|c|}
\hline Research variables & Relationship & C. R. & Loading Factor $(\lambda)$ & Probability \\
\hline \multirow[t]{6}{*}{ Service quality } & $\mathrm{Sqa} \rightarrow \mathrm{Sqa} 1$ & - & 0.774 & 0.000 \\
\hline & $\mathrm{Sqa} \rightarrow \mathrm{Sqa} 2$ & 3.214 & 0.749 & 0.000 \\
\hline & $\mathrm{Sqa} \rightarrow \mathrm{Sqa} 3$ & 4.115 & 0.805 & 0.000 \\
\hline & $\mathrm{Sqa} \rightarrow \mathrm{Sqa} 4$ & 4.326 & 0.812 & 0.000 \\
\hline & $\mathrm{Sqa} \rightarrow \mathrm{Sqa} 5$ & 3.336 & 0.768 & 0.000 \\
\hline & $\mathrm{Sqa} \rightarrow \mathrm{Sqa} 6$ & 3.115 & 0.735 & 0.000 \\
\hline \multirow[t]{3}{*}{ Customer relationship learning } & $\mathrm{Crl} \rightarrow \mathrm{Crll}$ & - & 0.872 & 0.000 \\
\hline & $\mathrm{Crl} \rightarrow \mathrm{Cr} 12$ & 4.857 & 0.655 & 0.000 \\
\hline & $\mathrm{Crl} \rightarrow \mathrm{Cr} 33$ & 6.682 & 0.734 & 0.000 \\
\hline \multirow{4}{*}{ Product quality } & Prq $\rightarrow$ Prq1 & - & 0.665 & 0.000 \\
\hline & Prq $\rightarrow$ Prq2 & 5.454 & 0.659 & 0.000 \\
\hline & $\operatorname{Prq} \rightarrow \operatorname{Prq} 3$ & 6.845 & 0.798 & 0.000 \\
\hline & Prq $\rightarrow$ Prq 4 & 6.827 & 0.759 & 0.000 \\
\hline \multirow{3}{*}{ Customer engagement } & $\mathrm{CE} \rightarrow$ Eng1 & - & 0.786 & 0.000 \\
\hline & $\mathrm{CE} \rightarrow$ Eng2 & 5.092 & 0.685 & 0.000 \\
\hline & $\mathrm{CE} \rightarrow$ Eng3 & 6.014 & 0.721 & 0.000 \\
\hline \multirow{4}{*}{ Customer value } & $\mathrm{CV} \rightarrow \mathrm{Vall}$ & 6.569 & 0.716 & 0.000 \\
\hline & $\mathrm{CV} \rightarrow \mathrm{Val} 2$ & 5.854 & 0.675 & 0.000 \\
\hline & $\mathrm{CV} \rightarrow \mathrm{Val} 3$ & 5.615 & 0.657 & 0.000 \\
\hline & $\mathrm{CV} \rightarrow \mathrm{Val} 4$ & 5.747 & 0.659 & 0.000 \\
\hline
\end{tabular}




\subsection{Goodness of Fit Test}

The results of data processing using a sample of 384 show Chi-square is 252,227 with a probability of 0.062 . Meanwhile, GFI, AGFI, TLI, CFI, RMSEA and CMIN / DF are 0.918, 0.904, 0.952, 0.956, 0.079, and 1.636, respectively and they are all within the range of acceptable values (Hair et al., 2016). The results of the analysis are shown in Fig. 2.

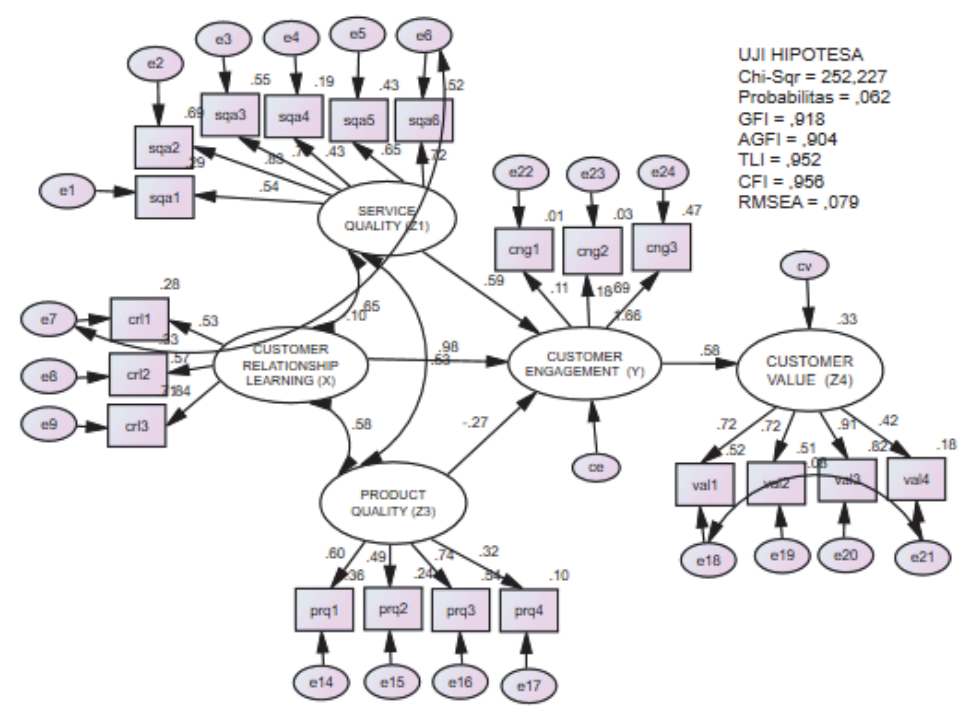

Fig. 2. Coefficient of Research Model Path

\subsection{Hypothesis testing}

Hypothesis testing is performed based on the estimated value of the significance of the parameters of the research model shown in Table 3.

Table 3

Hypothesis Testing

\begin{tabular}{|c|c|c|c|c|c|c|}
\hline $\mathrm{H}$ & Relationship & Standardized Coefficient & $\mathrm{SE}$ & C.R & $\mathrm{P}$ & Decision \\
\hline H1 & $\mathrm{SQA} \rightarrow \mathrm{CE}$ & 0.594 & 0.034 & 7.924 & 0.000 & accepted \\
\hline $\mathrm{H} 2$ & $\mathrm{CRL} \rightarrow \mathrm{CE}$ & 0.978 & 0.033 & 8.872 & 0.000 & accepted \\
\hline $\mathrm{H} 3$ & $\mathrm{PRQ} \rightarrow \mathrm{CE}$ & -0.268 & 0.034 & 2.753 & 0.048 & Reject \\
\hline $\mathrm{H} 4$ & $\mathrm{ENG} \rightarrow \mathrm{CV}$ & 0.577 & 0.037 & 6.001 & 0.000 & accepted \\
\hline
\end{tabular}

SQA: Service Quality, CRL: Customer Relationship Learning, PRQ: Product Quality, CE: Customer Engagement, CV: Customer Value.

Empirical results show that service quality influences and contributes to increasing customer involvement. These results give the meaning that if the quality of service is able to be directed and developed it will be able to trigger and increase customer involvement. The dominance of accuracy indicators on the results of this study, informs that, the problem of service accuracy is a major problem that companies should do to their customers. It is better if the service to customers is done quickly, precisely, and accurately. And also involves customers by providing opportunities, to correct employee work, and open communication and opportunities to share important information. With fast, precise and accurate service, the customer will give a positive response to the company's performance. Next the company's attention to customers, also needs to be done carefully through employees, and also pays attention to customer needs. This will also be positively responded by customers.

Empirical results also show that customer relationship learning (CRL) is influential and contributes to increasing customer involvement. The results of this evidence give the meaning that, when the company provides good CRL, it will have an impact on customer involvement. This is obtained because CRL is the process by which customers acquire purchasing and consumption knowledge, which will be applied to related behaviors in the future. The dominance of the repetition indicators in the results of this study, informs that, the problem of repetition is a major problem that the company should do for its customers. This can be confirmed by giving understanding to customers, ways to conduct banking transactions correctly, and providing guidance to customers, at the first time fill in the form to become a customer. Also provides a stimulus to remind customers that the company provides a place for customers to conduct convenient financial transactions. 
The empirical results indicate that product quality has a significant negative effect on customer involvement. The results of this evidence give the meaning that, when the company increases the quality of the product, customer involvement will decrease, this is in line with the reality that of premium quality products, the consumer will immediately be able to receive it, but if consumers still doubt the quality of the company's products, then consumer involvement will be high, because consumers will ask lots of questions and compare the company's products with competing products. Therefore, companies should always improve the quality of their products, so consumers will increasingly trust and be satisfied with the quality of the company's products.

Not many researchers have conducted research on customer engagement (CE). Moreover, research that connects the $\mathrm{CE}$ with customer value, therefore the use of CE variables in this research model, becomes a novelty.

The results of research have shown that CE has a significant effect on customer value (CV). This shows that the existence of $\mathrm{CE}$ owned by customers, contributes to CV. This happens because CE is a psychological condition that occurs because of interactions, co-creative experiences, and objects in the form of related services. The dominance of cognitive attachment indicators on $\mathrm{CE}$ variables on the results of this study, informs us that cognitive attachment problems are a major problem that companies should address, by providing information as well and as clear as possible. So customers can be a part that can market, and provide information about the company to others.

Empirical results show that $\mathrm{CE}$ becomes an intervening variable between service quality, customer relationship learning that contributes to increasing customer value. This has become one of the new findings, which was not hypothesized in this study.

\section{Conclusions}

From the results of testing the models in this study, we are able to explain the relationship between service quality, CRL, product quality, customer engagement (CE), and Customer Value (CV). The results of this study are significant contributions, especially in the science of marketing management, which are related to CE, and CV. Customer value is the customer's choice of a product or service that can truly satisfy the needs and desires of the customer. To be able to retain existing customers, companies must really pay attention to what becomes the needs and desires of customers.

This research is able to offer and produce concepts about CE, and CV in banking services. In the conceptual model offered, use emotional value, social value, performance, value, and value of many indicators as indicators of customer value variables. CV increases, as the value of $\mathrm{CE}$ increases customer relationship learning is the main determinant of CE value of banking service customers.

\section{References}

Ateke, B.W., \& Iruka, C.H. (2015). Investigating the relationship between customer involvement management and marketing performance in the manufacturing industry. International Journal of Research in Business Studies and Management, 2(9), 22-34.

Banytea, J., \& Dovaliene, A. (2014). Relations between customer engagement into value creation and customer loyalty. 19th International Scientific Conference; Economics and Management (ICEM), April 2014, 23-25. Riga, Latvia. DOI: 10.1016/j.sbspro. 2014.11.226

Brodie, R.J., Ilic, A., Juric, B., \& Hollebeek, L. (2011). Consumer engagement in a virtual brand community: An exploratory analysis. Journal of Business Research, 66(1), 105-114.

Bowden, J.L.H. (2009). The Process of Customer Engagement: A Conceptual Framework, December 2009. The Journal of Marketing Theory and Practice, 17(1), 63-74. DOI: 10.2753/MTP1069-6679170105

Chang, C.W., Huang, H.C., Wang, S.J., \& Lee, H. (2019). Relational bonds, customer engagement, and service quality. The Service Industries Journal. DOI: 10.1080/02642069.2019.1611784

Chen, Y.S., Ming, J.J.L., \& Chang, C.H. (2009). The positive effects of relationship learning and absorptive capacity on innovation performance and competitive advantage in industrial markets. Industrial Marketing Management, 38(2), 152158

Cialdini, R. (2010). Influence: The Psychology of Persuasion. 4thedition. International Edition. Singapore:McGrawHill.

Darwin, D., Suwanna, K., \& Theingi (2017). Building Customer Loyalty Through Service Quality, Customer Engagement and Commitment: The Case of Mobile Network Providers in Thailand (February 21, 2017). XVI International Business \& Economy Conference (IBEC) - Chile 2017. Available at SSRN: https://ssrn.com/abstract= 2921006.

Eng, T.-Y. (2005). The effects of learning on relationship value in a business network context. Journal of Business-to-Business Marketing, 12(4), 67-101. DOI: 10.1300/J033v12n04_03 
Ghofur, A., Ujianto, \& Halik, A. (2018). Effect of total quality service on customer value, customer relationship management, corporate image, customer pride and its impact on customer engagement private high education In East Java. International Journal of Business and Management Invention, 6(10), 80-87.

Hapsari, R., Clemes, M., \& Dean, D. (2017). The impact of service quality, customer engagement and selected marketing constructs on airline passenger loyalty, International Journal of Quality and Service Sciences, 9(1),21-40. Doi: 10.1108/IJQSS-07-2016-0048

Hapsari, R.D.V. (2015). The Impact of Customer Engagement and Selected Higher Order Marketing Constructs on Customer Loyalty: An Empirical Investigation of the Indonesian Airline Industry. Lincoln University 2015. https://core.ac.uk/download/pdf/35470242.pdf

Hair, J.F., Hult, G.T.M., Ringle, C., \& Sarstedt, M. (2016). A Primer on Partial Least Squares Structural Equation Modeling (PLS-SEM). Second Edition. Australia: SAGE Publications, Inc

Harryani, S. (2017). Customer Relationship Management Influence On Customer Value, Product Quality And Service Quality In Improving Customer Satisfaction And Its Implication On The Customer Loyalty. Jurnal Ekonomi Bisnis. 22(2), 160-165.

Hawkins, D.. Best, R. J., \& Coney, K. A. (2013). Consumer Behavior. NewYork:The McGraw-HillCompanies, Inc

Heri, H. (2017). Analysis the effect of service quality, customers value, customer satisfaction and customer trust on corporate image. OSR Journal of Business and Management (IOSR-JBM), 19(6), 38-46.

Hollebeek, L. D. (2011). Demystifying customer brand engagement: Exploring the loyalty nexus. Journal of Marketing Management, 27(7), 785-807.

Ishaq, M.I., Bhutta, M.H., Hamayun, A.A., Danish, R.Q, \& Hussain, N.M. (2014), Role of corporate image, product quality and customer value in customer loyalty: Intervening effect of customer satisfaction. Journal of Basic and Applied Scientific Research, 4(4), 89-97

Itani, O.S., Kassar, A.N, \& Loureiro, S.M.C. (2019). Value get, value give: The relationships among perceived value, relationship quality, customer engagement, and value consciousness. International Journal of Hospitality Management, 80(7), Pages 78-90. Doi: 10.1016/j.ijhm.2019.01.014

Johnston, R. (2017). Insights into service excellence, in Service Excellence als Impulsgeber., Springer, 17-35.

Lemeshow, S., Hosmer Jr, D. W., Klar, J., \& Lwanga, S. K. (1997). Adequacy Of Sample Size In Health Studies. New York: World Health Organization

Leong, M.K, Syuhaily, O., \& Laily, P. (2017). Relationship between consumer involvement and consumer engagement with consumer loyalty in tourism and hospitality industry. International Journal of Academic Research in Economics and Management Sciences, 6(4),72-91.

Manggarani, C.A. (2018). The role Of customer engagement on customer loyalty: A study at a private higher education institution. Hasanuddin Economics and Business Review 2(1), 71-82.

Nammir, D.S.S, Marane, Bayar, M.R., \& Ali, A.M. (2012). Determine the role of customer engagement on relationship quality and relationship performance. European Journal of Business and Management. 4(11), 27-37.

Naomi, D. (2015). Pengaruh online consumer engagement dalam website HijUp.com terhadap Kepercayaan Konsumen (Studi terhadap Konsumen HijUp.com). Jurnal Ilmiah Universitas Bakrie, 3(03), Aug. 2015.

Oswald A. Mascarenhas, O.A, Kesavan, R., \& Bernacchi, M. (2004). Customer value-chain involvement forco-creating customer delight. Journal of Consumer Marketing, 21(7), 486-496.

Panjaitan, H, \& Komari, A. (2018). The role of customer value and customer pride as variable mediation on customer engagement relationship with corporate image. International Review of Management and Marketing, 8(5), 1-8.

Rivai, A.R, \& Wahyudi (2016). The effort to create customer engagement on customer e_banking (Empirical Studies on Bank BNI Regional Semarang). Jurnal Dinamika Manajemen, 7(2), 191-205.

Selnes, F., \& Sallis, J. (2009). Relationship Learning with Key Customers, 99-103. Accessed 16 nov 2019. https://www.msi.org/reports/.

So, K. K. F., King, C., Sparks, B. A., \& Wang, Y. (2016). The role of customer engagement in building consumer loyalty to tourism brands. Journal of Travel Research, 55(1), 64-78.

Solomon, M.R. (2013). Consumer Behavior: Buying, Having and Being, 10thed. Pearson education limited, England.

Šonková, T., \& Grabowska, M. (2015). Customer engagement: transactional vs. relationship marketing. Journal of International Studies, 8(1), 196-207.

Vo, N. T., Chovancová, M., \& Tri, H. T. (2020). The impact of E-service quality on the customer satisfaction and consumer engagement behaviors toward luxury hotels. Journal of Quality Assurance in Hospitality \& Tourism, 21(5), 499-523.

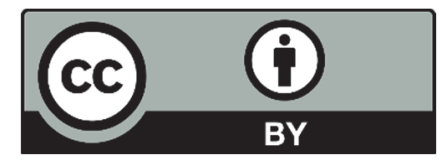

(C) 2021 by the authors; licensee Growing Science, Canada. This is an open access article distributed under the terms and conditions of the Creative Commons Attribution (CC-BY) license (http://creativecommons.org/licenses/by/4.0/). 